\title{
Physical and Spectral Characterization of Ni (II) Cu(II) Co(II) and Cd(II) Complexes with Schiff Base of Salicylaldehyde and 2-Aminopyridine Towards Potential Microbial Application
}

\author{
Md. Motahar Hossain 1, *, Md. Abul Bashar², Md. Nuruzzaman Khan³ ${ }^{3}$ Pijush Kanti Roy ${ }^{4}$, \\ Md. Abdul Mannan ${ }^{1}$, Md. Siddik Ali ${ }^{1}$, Md. Akhter Farooque ${ }^{1}$ \\ ${ }^{1}$ Department of Chemistry, University of Rajshahi, Rajshahi, Bangladesh \\ ${ }^{2}$ Department of Textile Engineering, Khwaja Yunus Ali University, Sirajgonj, Bangladesh \\ ${ }^{3}$ Department of Chemistry, Begum Rokeya University, Rangpur, Bangladesh \\ ${ }^{4}$ Department of Chemistry, Mawlana Bhashani Science and Technology University, Santosh, Tangail, Bangladesh \\ Email address: \\ motahar_chem $a$ gmail.com (Md. M. Hossain), motahar_chem $a$ ru.ac.bd (Md. M. Hossain) \\ ${ }^{*}$ Corresponding author \\ To cite this article: \\ Md. Motahar Hossain, Md. Abul Bashar, Md. Nuruzzaman Khan, Pijush Kanti Roy, Md. Abdul Mannan, Md. Siddik Ali, Md. Akhter \\ Farooque. Physical and Spectral Characterization of Ni (II) Cu(II) Co(II) and Cd(II) Complexes with Schiff Base of Salicylaldehyde and 2- \\ Aminopyridine Towards Potential Microbial Application. American Journal of Applied Chemistry. Vol. 6, No. 4, 2018 , pp. 147-155. \\ doi: $10.11648 /$ j.ajac.20180604.13
}

Received: September 1, 2018; Accepted: October 6, 2018; Published: October 29, 2018

\begin{abstract}
A Schiff base (SB) is derived from salicylaldehyde and 2-aminopyridine. The transition metal complexes of $\mathrm{N}$ i(II), Cu (II), Co and Cd (II) metal ions were prepared with this Schiff base (SB), which were used as ligand. Several physical tools, in particular; elemental analysis, molar conductivity, magnetic susceptibility, infrared spectroscopy (IR), electronic absorption spectroscopy (ESR) to investigate the chemical structure of the prepared transition metal complexes. The elemental analysis data shows the formation of 1:2 [M:2L] complex of the formula of $\mathrm{M}^{2+} \mathrm{L}_{2}$, where $\mathrm{M}^{2+}=\mathrm{Ni}$ (II), $\mathrm{Cu}$ (II), $\mathrm{Co}$ (II), $\mathrm{Cd}$ (II) and $\mathrm{L}=$ Schiff base (SB). The molar conductance (conductivity) measurements were revealed that all the complexes are nonelectrolyte in nature. The infrared (IR) spectral studies indicated the binding sites of the Schiff base ligand with the transition metal ions. The magnetic susceptibility measurements and electronic spectral results supported the predicted coordination geometry of the complexes and magnetic properties (para or dia-magnetic nature) of the complexes. The $\mathrm{Ni}(\mathrm{II}), \mathrm{Cu}(\mathrm{II}), \mathrm{Co}(\mathrm{II})$ ion forms high spin tetrahedral geometry, whereas Cd(II) ion forms low spin tetrahedral structure. The free Schiff base and its complexes have been tested for their antimicrobial activities against four human pathogenic (two gram-positive and two gramnegative) bacteria. The obtained results showed that only $\mathrm{Cu}(\mathrm{II})$ complex exhibited strong activity toward human pathogenic gram positive and gram negative bacteria whereas the $\mathrm{Ni}(\mathrm{II}), \mathrm{Co}(\mathrm{II})$ and $\mathrm{Cd}(\mathrm{II})$ complexes showed week to moderate antimicrobial activity compared with standard Kanamycin and Ampicillin.
\end{abstract}

Keywords: Schiff Base, Metal Complex, Spectral Studies, Antimicrobial Activity

\section{Introduction}

The chemical name of Salicylaldehyde is 2hydroxybenzaldehyde or ortho-hydroxybenzaldehyde and is an organic compound with the formula $\mathrm{C}_{7} \mathrm{H}_{6} \mathrm{O}_{2}$. Due to the hydroxy aromatic aldehydes group, aromatic nucleus holds two functional groups: a hydroxyl and aldehyde one, Salicilaldehyde is used as an important intermediate in the chemical industry, as well as in medicine manufacturing companies. It is also utilized in perfume, fragrances, dyes, pharmaceuticals, etc., [1-2]. The Schiff base ligands are derived by the condensation of a primary amine and an active carbonyl group and contain the azomethine group $(>\mathrm{C}=\mathrm{N}-)$. 
Salicylidimines are very important example of photochromism, where light absorption causes interconversion between enol-imine and keto-amine tautomers through intramolecular hydrogen transfer [3-4]. They have also been shown to exhibit a variety of biological activities with substituted salicylaldehyde compounds possessing higher activities $[5,44]$. It plays an important role in intense research on this class of compounds and their metal complexes [6]. Similarly, due to the presence of heteroatoms in the Schiff bases, the biological activity is also enhanced [3-8]. A very few metals are known to play very significant roles in biological processes in the human body. Particularly $\mathrm{Zn}$ (II) and $\mathrm{Cu}$ (II) are the ions are the second and third most abundant transition metals in human bodies. They are found either at the active sites or as structural components of a good number of enzymes [39, 43].

Metal complexes of the Schiff bases possess numerous applications including antibacterial, antifungal and other biological applications. It is also tremendously used in clinical, analytical, industrial sectors, catalysis [9-10]. Pb (II) complex with the Schiff base derived from salicylaldehyde and o-pheneylenediamine has been prepared and its geometry was investigated [11-12]. Mixed -ligand complexes of $\mathrm{Cu}$ (II) containing the Schiff base ligand derived from 2hydroxybenxaldehyde with 2-amino phenol/3-amino phenol and bidentate auxiliary ligands were synthesized and characterized by Kudrat et. al [23]. The authors observed that the complexes with Schiff bases exhibited the significant anti-microbial activity. The Schiff bases are important class of ligands in coordination chemistry and plays an important role as extensive applications in different fields [13-14, 2426]. A large number of the metal complexes with different electronic structures have been synthesized using Schiff base ligands [27-30]. In recent years, metal complexes of Schiff bases have attracted considerable attention due to their remarkable antibacterial, antifungal and antitumor activities [31-35, 44]. Previously, few transition metals complexes were synthesized with Schiff bases and studied their antimicrobial activity $[15,36]$. Most of the complexes play an important role to exhibit potential antimicrobial activity. Few transition metal complexes with Schiff base and studied their antimicrobial activities recently were reported [38]. It is also reported that certain metal-protein complexes of copper, magnesium, molybdenum, calcium, iron, zinc, chromium and vanadium are essential metallic elements and exhibit great biological activity, contributing in oxygen transport, electronic transfer reactions or the storage of ions, has generated massive attention in the study of systems containing these metals [41, 43].
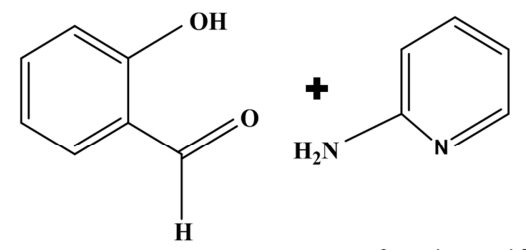

Salicylaldehyde
Keeping these facts in view the significance of metal in biology, as well as to continue our research work, we here in report the synthesis of the Schiff base by the condensation of salicylaldehyde and 2-aminopyridine. In addition complexation of this Schiff base with several transition metals $\mathrm{Ni}(\mathrm{II}), \mathrm{Cu}(\mathrm{II}), \mathrm{Co}(\mathrm{II})$ and $\mathrm{Cd}(\mathrm{II})$ ions. Also, we characterized these complexes on the basis of elemental analysis, conductivity and magnetic measurements and infrared spectral and electronic spectroscopy to explore the structure of the complexes. In addition, the antimicrobial activities of free Schiff base and of these complexes were also reported here.

\section{Experimental}

\subsection{Materials and Analytical Methods}

All the chemicals used in this work were reagent chemically pure and reagents grade (BDH/Aldrich). Solvents were purified and dried according to standard procedures. Melting points of all metal complexes were measured by an electro thermal melting point apparatus model no. AZ6512. Elemental analysis for carbon, hydrogen and nitrogen were performed by Perkin 2400 Organic Elemental Analyzer II at Kayama University, Japan. The SHERWOOD SCIENTIFIC Magnetic Susceptibility Balance was used for measuring magnetic susceptibility of the metal complexes. Infrared spectra as $\mathrm{KBr}$ disc was recorded with a NICOLET 310, FTIR Spectrophotometer, Belgium, from $4000-400 \mathrm{~cm}^{-1}$ in the Department of Metallurgy and Material Science, Bangladesh University of Engineering \& Technology (BUET), Dhaka, Bangladesh. UV-visible spectra were recorded with a SHIMADZU DOUBLE BEAM spectrophotometer (model UV-1200) from 200-900 nm in the Central Science Laboratory, University of Rajshahi, Bangladesh.

\subsection{Preparation of Schiff Base}

The Schiff base was prepared by mixing stoichiometric ratio of salicylaldehyde in ethanol with ethanolic solution of 2aminopyridine. Salicylaldehyde (0.9414 g, $10 \mathrm{mmol})$ in absolute ethanol $(20 \mathrm{~mL})$ was added to an ethanolic $(30 \mathrm{~mL})$ solution of 2- aminopyridine (1.230 g, $10 \mathrm{mmol})$. The mixture was stirred for 4 hours at ambient temperature. Then it was allowed to stand for 3 days at room temperature. The resulting solution was evaporated under vacuum to remove the solvent. The Product was collected by filtration, washed several times with ethanol and recrystallized from hot ethanol.

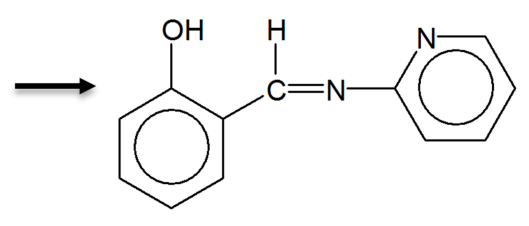

Schiff base (SB)

Figure 1. Reaction for the formation of Schiff base. 
The melting point of the product found to be $65^{\circ} \mathrm{C}$, and its purity was confirmed by TLC technique [36]. An orange red crystalline precipitate (product) was observed and then dried under vacuum desiccator over anhydrous $\mathrm{CaCl}_{2}$. The reaction scheme of the preparation of Schiff base (SB) is shown in figure 1 .

The general mechanism of imine formation (Figure 2) begins as a nucleophilic addition to the carbonyl group. In this case, the nucleophile is the amine, which reacts with the aldehyde or ketone to give an instable addition product called a carbinolamine. A carbinolamine is a compound with an amine group $\left(-\mathrm{NH}_{2}\right)-\mathrm{NHR}$ or $\left.-\mathrm{NR}\right)$ and a hydroxyl group to the same carbon as shown in Figure 2.<smiles>[R]NC(C)(O)[C-]=C[OH+]</smiles><smiles>[R]N=C(C)[C@H](C)[C@@H](C)O</smiles>

Carbinolamine

Figure 2. General mechanism for the formation of Schiff base.

\subsection{Preparation of Schiff Base Complexes}

$1 \mathrm{mmol}$ of salt $\mathrm{Ni}\left(\mathrm{NO}_{3}\right)_{2} \cdot 6 \mathrm{H}_{2} \mathrm{O}, \mathrm{Cu}\left(\mathrm{NO}_{3}\right)_{2} \cdot 3 \mathrm{H}_{2} \mathrm{O}$, $\mathrm{CoCl}_{2} \cdot 6 \mathrm{H}_{2} \mathrm{O}, \mathrm{Cd}\left(\mathrm{NO}_{3}\right)_{2} \cdot 4 \mathrm{H}_{2} \mathrm{O}$ were individually dissolved in $10 \mathrm{ml}$ of absolute ethanol. The Schiff base (SB) solution was added to these salts solution separately and stirred for 4 hours at ambient temperature and allowed to stand for half an hour. The precipitate was formed as Schiff base complex compounds and were filtered off and these were dried in vacuo over anhydrous $\mathrm{CaCl}_{2}$. The general reaction scheme of all the complexes is mentioned as:

$$
\mathrm{M}^{2+}+\mathrm{SB} \rightarrow\left[\mathrm{M}(\mathrm{SB})_{2}\right] .
$$

Where, $\mathrm{M}^{2+}=\mathrm{Ni}(\mathrm{II}), \mathrm{Cu}(\mathrm{II}), \mathrm{Co}(\mathrm{II})$ and $\mathrm{Cd}(\mathrm{II})$ ions, $\mathrm{SB}=$ Schiff base.

\subsection{Test for Antimicrobial Evaluation}

The complexes were screened by the agar well diffusion method for their antimicrobial activity

against various types of bacteria, gram positive- Bacillus cereus, Streptococcus agalactiae, and gram-negativeEscherichia coli, Shigella dysenteriae, regarded as pathogen to man. All media and bacteria suspension were prepared using a suitable method. The in-vitro evaluation of antimicrobial activities was performed according to the diffusion technique [13]. The bacteria were grown in nutrient broth at $37^{\circ} \mathrm{C}$ for 24 hours according to the previous literatures [41, 42]. The complexes were tested using diffusion on solid media. Sterile $(5 \mathrm{~mm})$ diameter sensitivity paper disc was impregnated with concentration of dimethylformamide (DMF) and their bimetallic complexes at concentration of $50 \mu \mathrm{g} \mathrm{cm}^{-3}$ and placed in the nutrient agar. The plates were then incubated for 24 hours. The results were recorded by measuring the growth inhibition (\% zones of inhibition) surrounding the disc.

\section{Results and Discussion}

All the complexes are stable at room temperature and are insoluble in common organic solvents but are soluble in DMSO, DMF and $\mathrm{CHCl}_{3}$

\subsection{Elemental Analysis and Conductivity Measurement}

Elemental analysis and physical properties of the complexes are listed in Table 1 and Table 2. The analytical data were in good agreement with the proposed empirical formula of the complexes. The conductance values of the complexes revealed that all the complexes are non-electrolyte in nature [16]. The obtained values imply that no anions are present outside the coordination sphere in all the complexes [37].

Table 1. Elemental analysis of the ligand (Schiff base) and the complexes.

\begin{tabular}{|c|c|c|c|c|c|c|}
\hline \multirow{2}{*}{ Ligand and Complexes } & \multicolumn{2}{|l|}{ \% Carbon } & \multicolumn{2}{|c|}{ \% Hydrogen } & \multicolumn{2}{|l|}{ \% Nitrogen } \\
\hline & Calculated & Found & Calculated & Found & Calculated & Found \\
\hline $\mathrm{SB}\left(\mathrm{C}_{12} \mathrm{H}_{10} \mathrm{~N}_{2} \mathrm{O}\right)$ Orangered crystal & 72.73 & 72.59 & 5.04 & 4.96 & 14.14 & 14.02 \\
\hline$\left[\mathrm{Ni}\left(\mathrm{C}_{12} \mathrm{H}_{10} \mathrm{~N}_{2} \mathrm{O}\right)_{2}\right]$ & 63.33 & 62.42 & 4.39 & 4.13 & 12.31 & 11.75 \\
\hline$\left[\mathrm{Cu}\left(\mathrm{C}_{12} \mathrm{H}_{10} \mathrm{~N}_{2} \mathrm{O}\right)_{2}\right]$ & 62.67 & 61.52 & 4.35 & 4.04 & 12.18 & 11.86 \\
\hline$\left[\mathrm{Co}\left(\mathrm{C}_{12} \mathrm{H}_{10} \mathrm{~N}_{2} \mathrm{O}\right)_{2}\right]$ & 63.30 & 62.48 & 4.39 & 3.80 & 12.30 & 11.52 \\
\hline$\left[\mathrm{Cd}\left(\mathrm{C}_{12} \mathrm{H}_{10} \mathrm{~N}_{2} \mathrm{O}\right)_{2}\right]$ & 56.67 & 56.06 & 3.93 & 3.12 & 11.02 & 10.50 \\
\hline
\end{tabular}

Where, $\mathrm{SB}=$ Schiff base. 
Table 2. Physical properties of the ligand (Schiff base) and complexes.

\begin{tabular}{lllll}
\hline Complexes & Colour & Melting point or decomposition tem. $\left( \pm \mathbf{5}^{\circ} \mathbf{C}\right)$ & \% Yield & Molar conductance $\left(\mathbf{o h m}^{-2} \mathbf{c m}^{2} \mathbf{~ m o l}^{\mathbf{1}}\right)$ \\
\hline$\left[\mathrm{Ni}\left(\mathrm{C}_{12} \mathrm{H}_{10} \mathrm{~N}_{2} \mathrm{O}\right)_{2}\right]$ & Green & 280 (above) & 62 & 15.4 \\
{$\left[\mathrm{Cu}\left(\mathrm{C}_{12} \mathrm{H}_{10} \mathrm{~N}_{2} \mathrm{O}\right)_{2}\right]$} & Black & 149 & 59 & 15.6 \\
{$\left[\mathrm{Co}\left(\mathrm{C}_{12} \mathrm{H}_{10} \mathrm{~N}_{2} \mathrm{O}\right)_{2}\right]$} & Brown & 80 & 61 & 17.2 \\
{$\left[\mathrm{Cd}\left(\mathrm{C}_{12} \mathrm{H}_{10} \mathrm{~N}_{2} \mathrm{O}\right)_{2}\right]$} & yellow & 184 & 65 & 14.3 \\
$\mathrm{SB}\left(\mathrm{C}_{12} \mathrm{H}_{10} \mathrm{~N}_{2} \mathrm{O}\right)$ & Orange red crystal & 65 & & \\
\hline
\end{tabular}

Where, $\mathrm{SB}=$ Schiff base.

\subsection{IR Spectral Studies}

The Infrared spectral data of the ligand and complexes were listed in Table 3. The spectral data of the ligand showed a strong absorption band at $(1580-1640) \mathrm{cm}^{-1}$ due to $\mathrm{v}(\mathrm{C}=\mathrm{N})$ stretching [17-18]. Band at (3020-3165) $\mathrm{cm}^{-1}$ due to aromatic
$v(\mathrm{C}-\mathrm{H})$ stretching. The Band at $(500-600) \mathrm{cm}^{-1}$ due to $v(\mathrm{M}-$ N) stretching [19-20], which indicated the co-ordination of ligand (SB) through $\mathrm{N}$ atom to the metals ion. Band at (440500) $\mathrm{cm}^{-1}$ due to $v(\mathrm{M}-\mathrm{O})$ stretching, which indicated the complexation have taken place to the metal through the deprotonated $\mathrm{O}$ atom of phenolic $\mathrm{OH}$ moiety.

Table 3. IR spectral data of the ligand and metal complexes.

\begin{tabular}{llllll}
\hline Complexes & $\mathbf{v}(\mathbf{O}-\mathbf{H}) . \mathbf{c m}^{-\mathbf{1}}$ & $\mathbf{v}(\mathbf{C}=\mathbf{N}) \cdot \mathbf{c m}^{-\mathbf{1}}$ & $\mathbf{v}(\mathbf{C}-\mathbf{H})$ of aromatic $\mathbf{~ c m}^{-\mathbf{1}}$ & $\mathbf{v}(\mathbf{M}-\mathbf{O}) \mathbf{c m}^{-\mathbf{1}}$ & $\mathbf{v}(\mathbf{M}-\mathbf{N}) \mathbf{c m}^{-\mathbf{1}}$ \\
\hline$\left[\mathrm{Ni}\left(\mathrm{C}_{12} \mathrm{H}_{10} \mathrm{~N}_{2} \mathrm{O}\right)_{2}\right]$ & 3434.98 & 1609.88 & 3070.26 & 447.56 & 557.35 \\
{$\left[\mathrm{Cu}\left(\mathrm{C}_{12} \mathrm{H}_{10} \mathrm{~N}_{2} \mathrm{O}\right)_{2}\right]$} & 3435.56 & 1614.06 & 3061.63 & 448.34 & 555.96 \\
{$\left[\mathrm{Co}\left(\mathrm{C}_{12} \mathrm{H}_{10} \mathrm{~N}_{2} \mathrm{O}\right)_{2}\right]$} & 3415.20 & 1622.84 & 3012.61 & 441.20 & 520.34 \\
{$\left[\mathrm{Cd}\left(\mathrm{C}_{12} \mathrm{H}_{10} \mathrm{~N}_{2} \mathrm{O}\right)_{2}\right]$} & 3397.86 & 1622.99 & 3008.40 & 444.47 & 541.92 \\
$\mathrm{SB}\left(\mathrm{C}_{12} \mathrm{H}_{10} \mathrm{~N}_{2} \mathrm{O}\right)$ & 3415.35 & 1623.25 & 3015.93 & & \\
\hline
\end{tabular}

Where, SB = Schiff base.

The infrared spectra of Schiff base and its complexes with transition metals of $\mathrm{Ni}(\mathrm{II}), \mathrm{Cu}(\mathrm{II}), \mathrm{Co}(\mathrm{II})$ and $\mathrm{Cd}(\mathrm{II})$ are given below in Figure 3 (A), (B), (C), (D) and E, respectively.

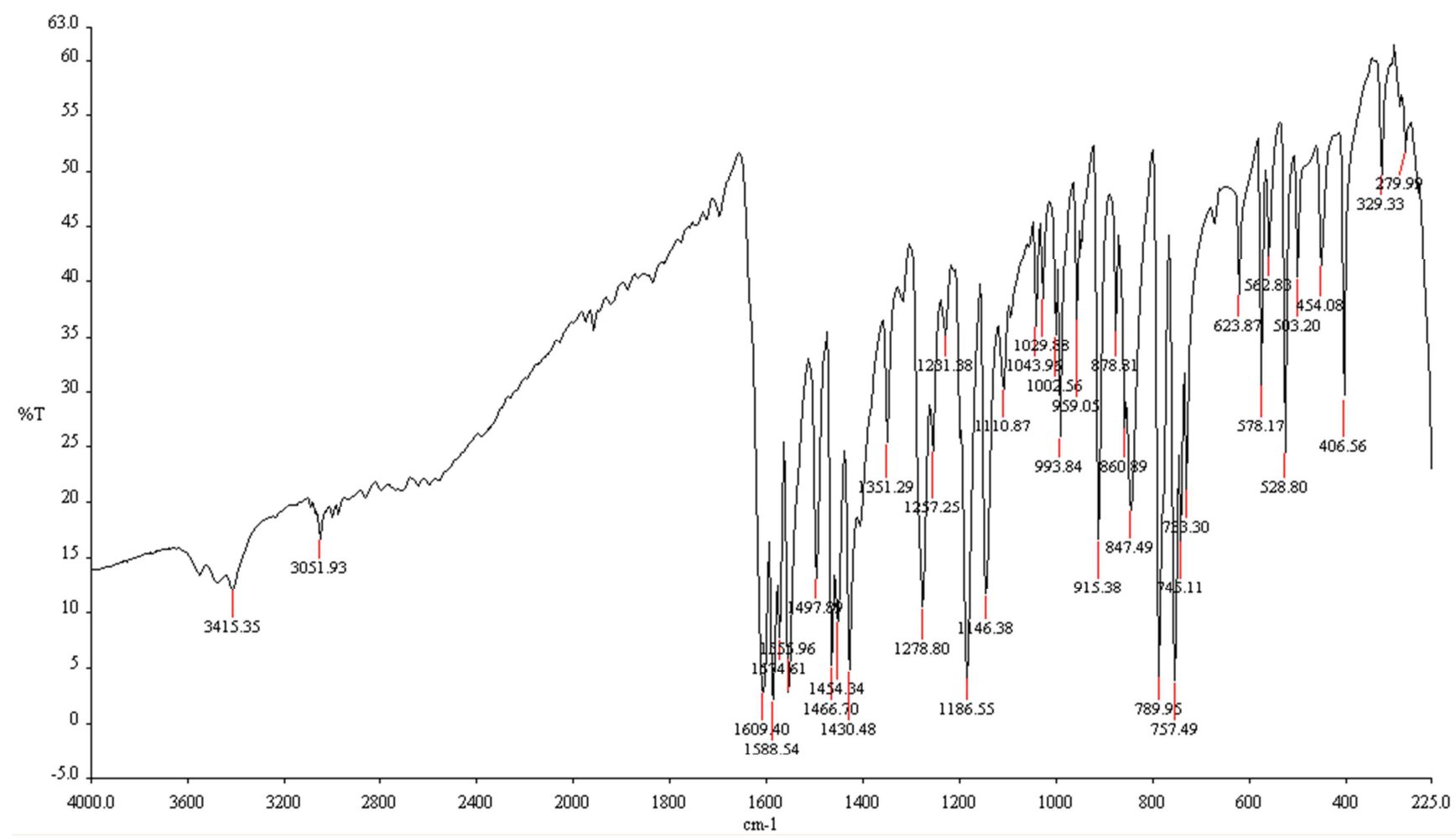




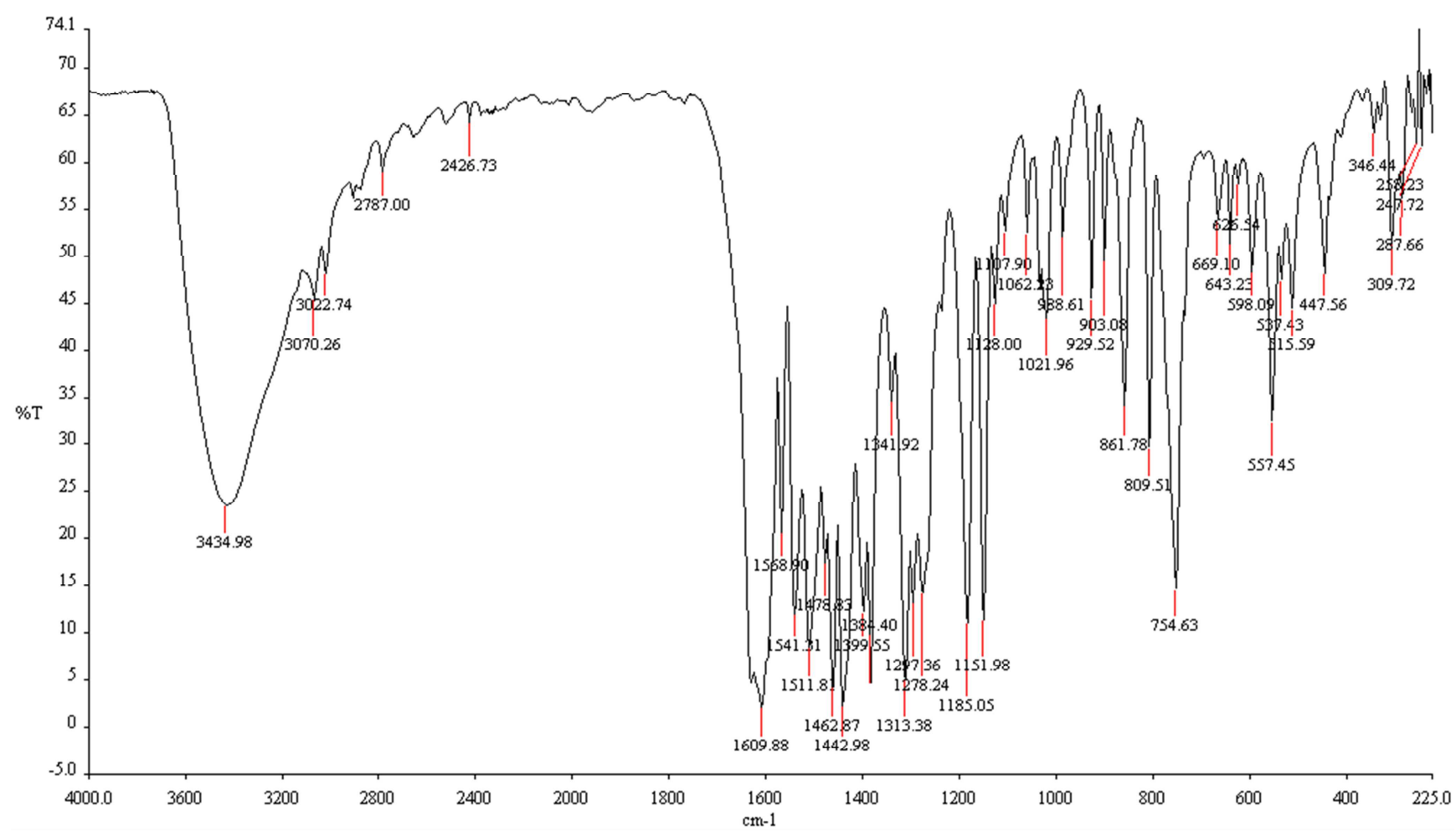

B

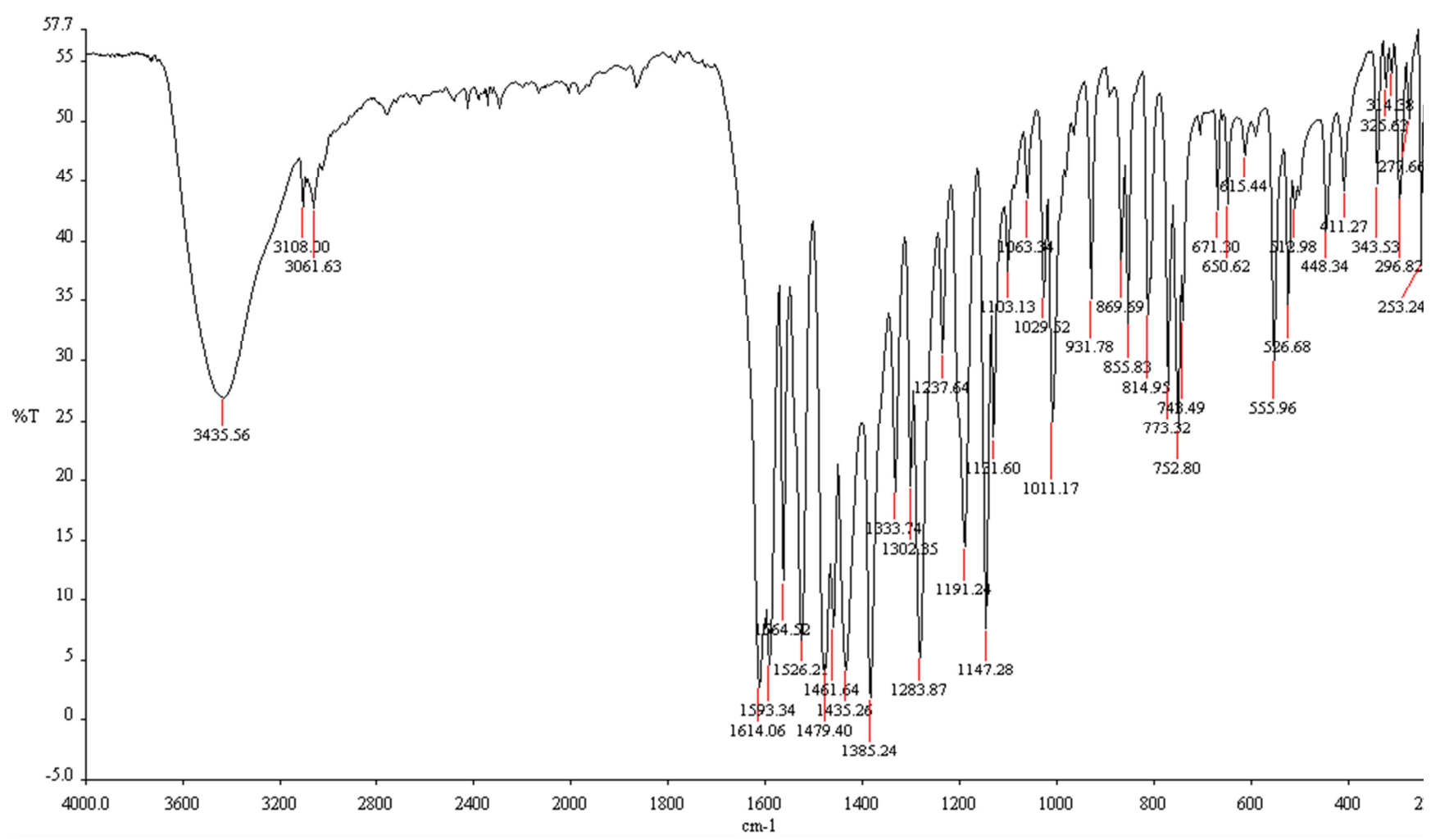




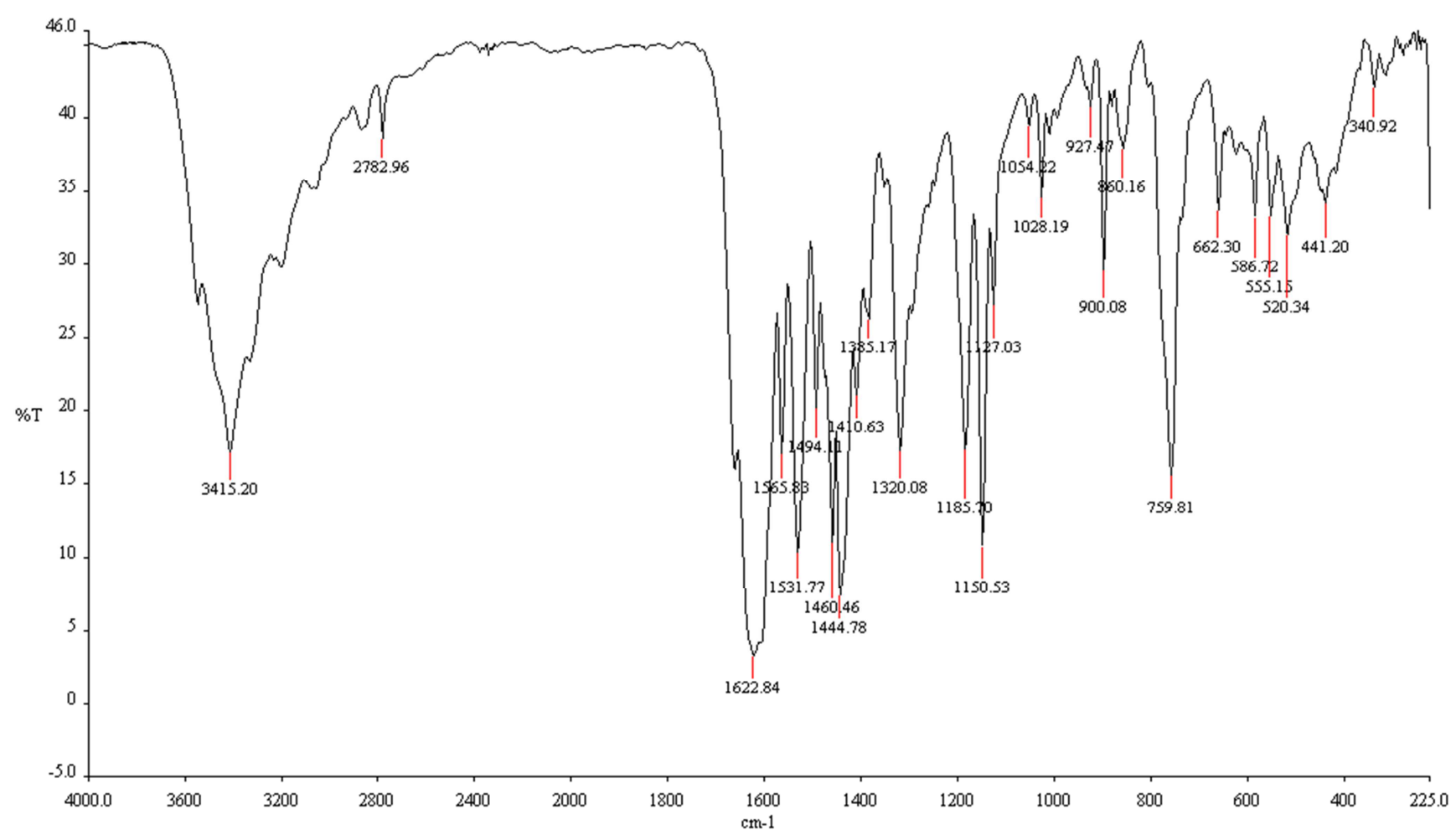

$\mathrm{D}$

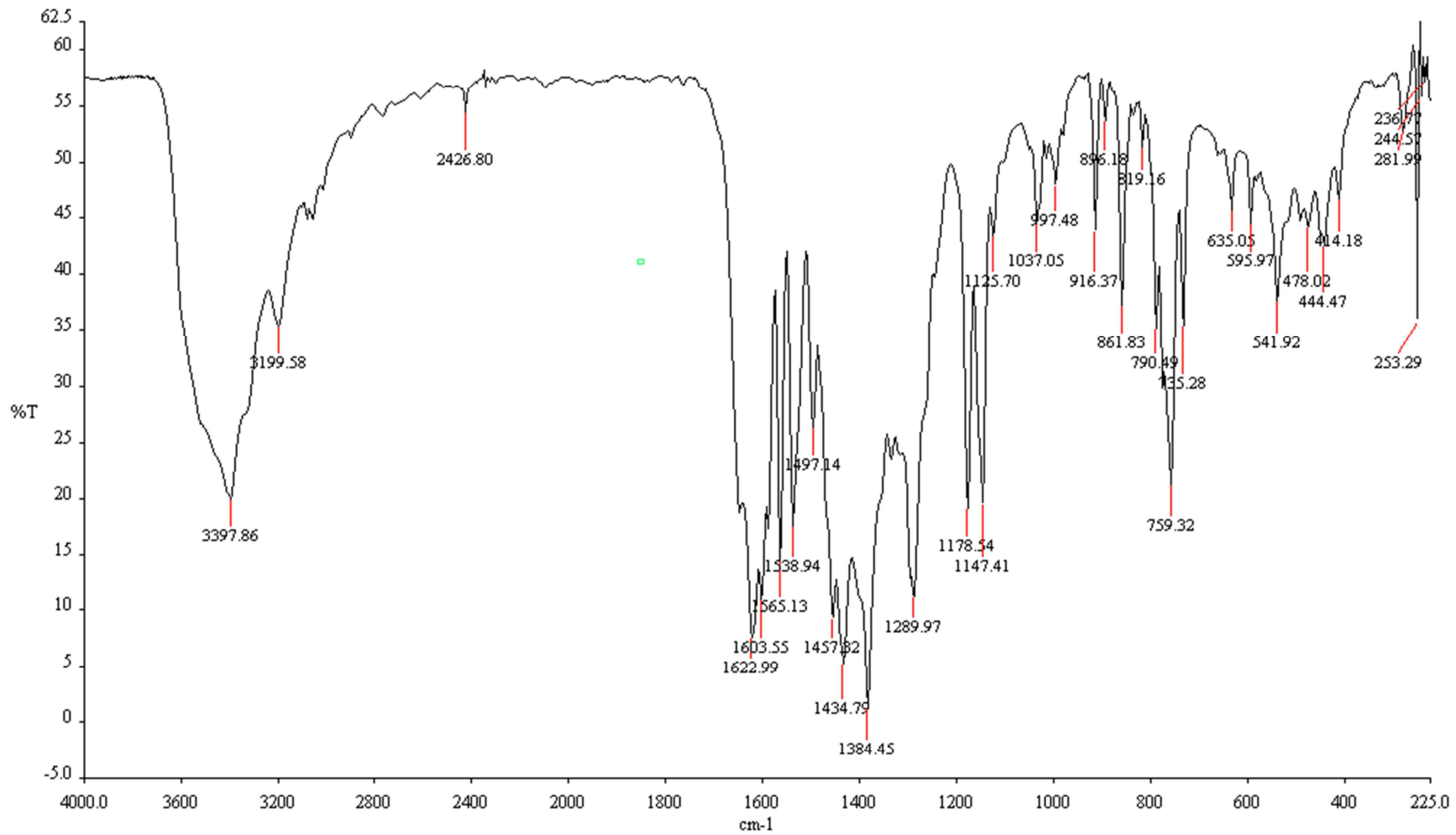

E

Figure 3. The IR spectrum of Schiff base [A] and its complexes of Ni(II) [B], Cu(II) [C], Co(II)[D] and Cd(II) [E].

\subsection{Magnetic Moment and Electronic Spectra}

The magnetic moment values were measured of the complexes at ambient temperature and the results are given in Table-4. The observed magnetic moment values of $\mathrm{Ni}(\mathrm{II})$ complex is 3.75 B.M. corresponding two unpaired electrons. It implies from the magnetic moment data that $\mathrm{Ni}(\mathrm{II})$ complex is a high spin tetrahedral complex. The magnetic moment value of $\mathrm{Cu}$ (II) complex was found to be $1.12 \mathrm{~B} . \mathrm{M}$. which corresponding to one unpaired electron. It revealed 
that $\mathrm{Cu}(\mathrm{II})$ complex is also a high spin tetrahedral complex. The magnetic moment value of Co(II) complex is 4.05 B.M. corresponding to three unpaired electrons. From the magnetic moment data, it can be observed that Co(II) complex is a high spin tetrahedral complex. The observed magnetic moment value revealed that the $\mathrm{Cd}$ (II) complex is diamagnetic which indicating the absence of unpaired electron. It appears from the magnetic moment data that
Cd(II) complex is a low spin tetrahedral complex [21].

The electronic spectral data of the complexes are shown in Table 5. The UV-visible spectrum for the $\mathrm{Ni}(\mathrm{II}), \mathrm{Cu}(\mathrm{II})$, $\mathrm{Co}(\mathrm{II})$ and $\mathrm{Cd}(\mathrm{II})$ complexes were found to be 270, 402, 400 $\mathrm{nm}$, and two bands at $398 \mathrm{~nm}$ and $302 \mathrm{~nm}$, respectively. These electronic spectra bands exhibited in the region of 200$420 \mathrm{~nm}$, due to charge transfer only [22].

Table 4. Magnetic moment data of the complexes.

\begin{tabular}{|c|c|c|c|c|c|c|c|c|c|c|}
\hline Complexes & $\begin{array}{l}\text { Length of } \\
\text { the sample, } \\
\text { 'I' in cm }\end{array}$ & $\begin{array}{l}\text { weight of } \\
\text { the sample } \\
\text { 'm' in } g\end{array}$ & $\begin{array}{l}\text { Susceptibili } \\
\text { ty of the } \\
\text { empty } \\
\text { tube, Ro }\end{array}$ & $\begin{array}{l}\text { Susceptibility } \\
\text { of the sample } \\
\text { with tube. } R\end{array}$ & $\begin{array}{l}\text { Mass } \\
\text { Susceptibility } \\
\chi_{\mathrm{g}} \times 10^{-6} \text { C.G.S } \\
\text { unit }\end{array}$ & $\begin{array}{l}\text { Molecul-ar } \\
\text { weight of } \\
\text { the sample, } \\
\text { M }\end{array}$ & $\begin{array}{l}\text { Molecul-ar } \\
\text { susceptibility, } \\
\chi_{\mathrm{m}} \times 10^{-6} \\
\text { C.G.S. unit }\end{array}$ & $\begin{array}{l}\text { Dimagnetic } \\
\text { correction } \chi_{\mathrm{L}} \\
\times 10^{-6} \text { C.G.S. } \\
\text { unit }\end{array}$ & $\begin{array}{l}\chi_{\mathrm{m}}{ }^{\text {corr }} \times 10^{-6} \\
\text { C.G.S. unit }\end{array}$ & $\begin{array}{l}\mu_{\text {eff }} \text { in } \\
\text { B.M. }\end{array}$ \\
\hline$\left[\mathrm{Ni}\left(\mathrm{C}_{12} \mathrm{H}_{10} \mathrm{~N}_{2} \mathrm{O}\right)_{2}\right]$ & 2.3 & 0.0247 & -62 & +02 & 12.431 & 454.69 & 5652.25 & -232.24 & 5884.49 & 3.75 \\
\hline$\left[\mathrm{Cu}\left(\mathrm{C}_{12} \mathrm{H}_{10} \mathrm{~N}_{2} \mathrm{O}\right)_{2}\right]$ & 2.2 & 0.0566 & -67 & -59 & 0.648 & 459.5 & 297.75 & -232.26 & 530.01 & 1.12 \\
\hline$\left[\mathrm{Co}\left(\mathrm{C}_{12} \mathrm{H}_{10} \mathrm{~N}_{2} \mathrm{O}\right)_{2}\right]$ & 1.8 & 0.0335 & -65 & +65 & 14.570 & 454.93 & 6628.33 & -232.26 & 6860.59 & 4.05 \\
\hline$\left[\mathrm{Cd}\left(\mathrm{C}_{12} \mathrm{H}_{10} \mathrm{~N}_{2} \mathrm{O}\right)_{2}\right]$ & 1.8 & 0.0534 & -64 & -74 & -1.093 & 508.14 & -555.69 & -234.26 & -789.95 & dia \\
\hline
\end{tabular}

Table 5. Electronic spectral data of complexes.

\begin{tabular}{ll}
\hline Complexes & $\boldsymbol{\lambda}_{\max }(\mathbf{n m})$ \\
\hline$\left[\mathrm{Ni}\left(\mathrm{C}_{12} \mathrm{H}_{10} \mathrm{~N}_{2} \mathrm{O}\right)_{2}\right]$ & 270,402 \\
{$\left[\mathrm{Cu}\left(\mathrm{C}_{12} \mathrm{H}_{10} \mathrm{~N}_{2} \mathrm{O}\right)_{2}\right]$} & 400 \\
{$\left[\mathrm{Co}\left(\mathrm{C}_{12} \mathrm{H}_{10} \mathrm{~N}_{2} \mathrm{O}\right)_{2}\right]$} & 398 \\
{$\left[\mathrm{Cd}\left(\mathrm{C}_{12} \mathrm{H}_{10} \mathrm{~N}_{2} \mathrm{O}\right)_{2}\right]$} & 302 \\
\hline
\end{tabular}

\section{Structure of the Complexes}

From the above discussion (elemental analysis, conductivity measurement, magnetic moment and electronic spectra, IR spectra) and the literature review, it can be concluded that the possible structures of the complexes are given below in Figure 4.

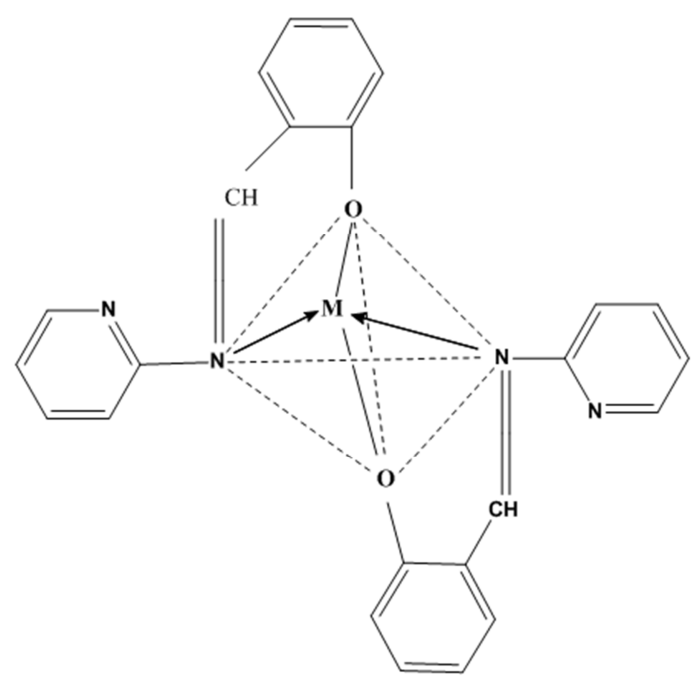

Here, $\mathrm{M}=\mathrm{Ni}(\mathrm{II}), \mathrm{Cu}(\mathrm{II}), \mathrm{Co}(\mathrm{II})$ and $\mathrm{Cd}(\mathrm{II})$.

Figure 4. Proposed tetrahedral structure of the complexes

\section{Antimicrobial Activity of the Metal Complexes}

Antimicrobial activities of the test samples are expressed by measuring the zone of inhibition of organisms observed around the area. The results for all the complexes are illustrated in Table 6 and Figure 5. The results revealed that the complexes are more microbial activity than the free metal ions or ligands. From the results it was clear that the $\mathrm{Cu}$ (II) complex showed more potent microbial activity against all kinds (gram- positive and gram-negative) of pathogenic bacterial compared to standard kanamycin and ampicillin. The rest of the complexes of $\mathrm{Ni}$ (II), Co (II) and Cd (II) with Schiff base exhibited moderate to less activity against four pathogenic bacterial.

Table 6. Antibacterial activity of the metal complexes.

\begin{tabular}{|c|c|c|c|c|}
\hline \multirow{3}{*}{ Compounds } & \multicolumn{4}{|c|}{ Zone of inhibition, diameter in $\mathrm{mm}$} \\
\hline & \multicolumn{2}{|c|}{ Gram-negative } & \multicolumn{2}{|c|}{ Gram-positive } \\
\hline & $\begin{array}{l}\text { Escherichia } \\
\text { coli }\end{array}$ & $\begin{array}{l}\text { Shigella } \\
\text { dysenteriae }\end{array}$ & $\begin{array}{l}\text { Bacillus } \\
\text { cereus }\end{array}$ & $\begin{array}{l}\text { Streptococcus } \\
\text { agalactiae }\end{array}$ \\
\hline$\left[\mathrm{Ni}\left(\mathrm{C}_{12} \mathrm{H}_{10} \mathrm{~N}_{2} \mathrm{O}\right)_{2}\right]$ & & 8 & & \\
\hline$\left[\mathrm{Cu}\left(\mathrm{C}_{12} \mathrm{H}_{10} \mathrm{~N}_{2} \mathrm{O}\right)_{2}\right]$ & 20 & 23 & 22 & 24 \\
\hline$\left[\mathrm{Co}\left(\mathrm{C}_{12} \mathrm{H}_{10} \mathrm{~N}_{2} \mathrm{O}\right)_{2}\right]$ & 5 & 13 & 7 & 9 \\
\hline$\left[\mathrm{Cd}\left(\mathrm{C}_{12} \mathrm{H}_{10} \mathrm{~N}_{2} \mathrm{O}\right)_{2}\right]$ & 10 & - & 9 & 6 \\
\hline Kanamycin-30 & 32 & 28 & 33 & 31 \\
\hline $\begin{array}{l}\text { Control disc (Only } \\
\text { Solvent) }\end{array}$ & Nill & Nill & Nill & Nill \\
\hline
\end{tabular}

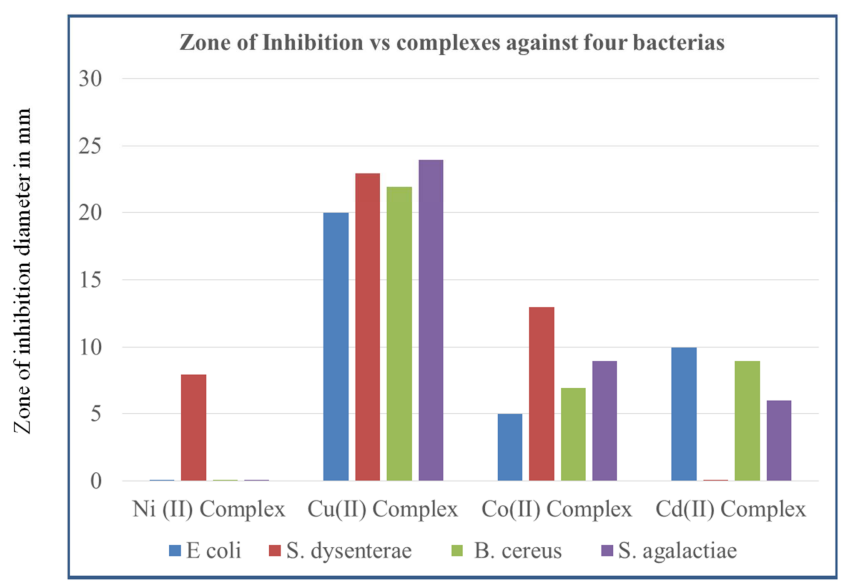

Figure 5. Antimicrobial activities of $\mathrm{Ni}$ (II), $\mathrm{Cu}(\mathrm{II}), \mathrm{Co}(\mathrm{II})$ and $\mathrm{Cd}(\mathrm{II})$ complexes with Schiff base. 


\section{Conclusion}

Magnetic susceptibility measurement indicated that the Ni(II), Cd(II) and Zn(II) complexes with Schiff base are the diamagnetic and the rest of the complexes are paramagnetic in nature. The IR spectral data showed that all the metals are coordinated through two $\mathrm{N}$ (N of $-N=C H-$ and $N$ of pyridine of Schiff base) atoms of the Schiff base coordinate with all the metal ions. The magnetic moment data revealed that the $\mathrm{Ni}(\mathrm{II}), \mathrm{Cu}(\mathrm{II}), \mathrm{Co}(\mathrm{II})$ with Schiff base are tetrahedral high spin complexes whereas $\mathrm{Cd}(\mathrm{II})$ complex is a low spin tetrahedral geometry. The electronic spectral data were confirmed that all the complexes are tetrahedral structure. Based on these above results and facts, the structures of complexes have been proposed as shown in figure 4:

The $\mathrm{Cu}$ (II) complex shows the highest (more potent) antimicrobial activity against gram-positive and gramnegative pathogenic bacteria according to standard kanamycin and ampicillin. $\mathrm{Ni}(\mathrm{II}), \mathrm{Co}(\mathrm{II})$, and $\mathrm{Cd}(\mathrm{II})$ complexes with Schiff base exhibit moderate to less antimicrobial activity against examined pathogenic bacteria.

\section{Acknowledgements}

The corresponding author would like to acknowledge the financial support from Ministry of Science and Technology (MOST), Dhaka, Bangladesh. The acknowledgement should also go to the Central Science Laboratory, Rajshahi University, as well as chairman, Department of Chemistry, University of Rajshahi, Bangladesh for necessary instrumental support.

\section{References}

[1] Crişan R, Modra D (2013) The synthesis of salicylaldehyde varying different parameters. J. West University of Timişoara, Series of Chemistry 22: 57-66.

[2] Simmonds J, Robinson GK (1998) Formation of Benzaldehyde by Pseudomonas putida ATCC 12633. Appl. Microbial Biotechnol 50:353-358.

[3] Dueke-Eze CU, Fasina TM, Idika N (2011) Synthesis, electronic spectra and inhibitory study of some Salicylaldehyde Schiff bases of 2-aminopyridine. African Journal of Pure and Applied Chemistry 5:13-18.

[4] Schiff W, Szady CA, Grech E, Przybylski P, Brzezinski B (2002) Spectroscopic studies of new Schiff and SchiffMannich bases of ortho-derivatives of 4-bromophenol. J. Mol. Struct. 643:115-121.

[5] Prisakar VI, Tsapkov VI, Buracheeva SA, Byrke MS, Gulya AP (2005) Synthesis and antimicrobial activity of coordination compounds of copper with substituted salicylaldehyde thiosemicarbazones. Pharm. Chem. J. 39: 3032.

[6] Naturforsch Z, Pelttari E, Karhumaki E, Langshaw J, Perakyla $\mathrm{H}$, Elo H (2007) Antimicrobial properties of substituted salicylaldehyde and related compounds. J. Biosci. 62C: 487-
497.

[7] Tsapkov VI, Prisacar VI, Buracheva SA, Lazakovich DV, Gulya AP (2008) Synthesis and antimicrobial activity of sulfazine-containing copper(II) coordination compounds with substituted salicylaldehydebenzoylhydrazones. Pharm. Chem. J. 42: 523-526.

[8] Shi L, Ge HM, Tan SH, Li HQ, Song YC, Zhu HL, Tan RX (2007) Synthesis and antimicrobial activity of Schiff bases derived from 5-chloro-salicylaldehyde. Eur. J. Med. Chem.42: 558-564.

[9] Uddin MN, Chowdhury DA, Rony MM, Halim ME (2014) Metal complexes of Schiff bases derived from 2thiophenecarboxaldehyde and mono/diamine as the antibacterial agents. j. Science publishing group 2: 6-14.

[10] Jamuna K, Naik BR, Sreenu B, Seshaiah K (2012) Synthesis, characterization and antibacterial activity of $\mathrm{Cu}(\mathrm{II})$ and $\mathrm{Fe}(\mathrm{III})$ complexes of a new tridentate Schiff base ligand. J. Chem. Pharm. Res.4: 4275-4282.

[11] Uddin MM, Salam MA, Sultana J (2015) Pb(II) complexes of Schiff bases derived from benzoylhydrazine as the antibacterial agents", J. Science publishing group 3:7-14.

[12] El-Ajaily M-M, Abdlseed F-A, Gweirif B, "Preparation, characterization and antibacterial activity of some metal ion complexes", E-Journal of Chem., vol. 4, pp. 461-466, 2007).

[13] Sharif SAI, El-Tajoury AN, Elamar AA (2011) Preparation and Antibacterial Activity of Mixed Ligand Complexes of $\mathrm{Co}(\mathrm{II}), \mathrm{Ni}(\mathrm{II}), \mathrm{Cu}(\mathrm{II})$ and $\mathrm{Cd}(\mathrm{II})$ Derived from 1-Phenylazo-2naphthol and Salicylaldehyde. E-Journal of Chemistry 8: 4348.

[14] Ran X, Wang L, Cao D, Lin Y, Hao J (2011) Synthesis, characterization and in vitro biological activity of cobalt(II), copper(II) and zinc(II) Schiff base complexes derived from salicylaldehyde and D, L-selenomethionine. Appl. Organometal. Chem. 25: 9-15.

[15] Zahan MKE, Islam MS, Bashar MA (2015) Synthesis, Characterization and antimicrobial activity of Some Metal Complexes of $\mathrm{Mn}(\mathrm{II}), \mathrm{Fe}(\mathrm{III}) \mathrm{Co}(\mathrm{II}), \mathrm{Ni}(\mathrm{II}), \mathrm{Cu}(\mathrm{II})$ and $\mathrm{Sb}(\mathrm{III})$ Containing Bidentate Schiff base of SMDTC. Russian Journal of general chemistry 85: 667-672.

[16] Geary WJ (1971) The use of conductivity measurements in organic solvents for the characterization of coordination compounds. Coord. Chem. Rev. 7: 81-122.

[17] Shamsuddin Ahamed AK, Benui -D, Siddique A, Datta M (1999) J. Bang. Chem. Soc. 12: 25.

[18] Sadler PJ, Nast M, Narayaran MM (1989) The design of metal complex as anticancer drugs. Murtius-Nijhoff, Boston.

[19] Hutchinson B, Takemoto J, Nakamoto K (1970) Metal isotope effect on metal-ligand vibration. II. Tris complexes of 2, 2bipyridine and 1, 10-phenanthroline. J. Am. Chem. Soc. 92: 3335 .

[20] Saito Y, Takemoto J, Hutchinson B, Nakamoto K (1972) Infrared studies of coordination compounds containing lowoxidation state metals. I. Tris (2,-2'-bipyridine) and tris (1, 10phenanthroline) complexes. Inorg. Chem. 11: 2003.

[21] Figgis B-N, Lewis J (1964) The magnetic properties of transition metal complexes. Prog. Inorg. Chem. 6: 73. 
[22] Lever ABP (1984) Inorganic Electronic Spectroscopy, $2^{\text {nd }}$ Edn. Elsevier.

[23] Shampa JA, Islam, MR, Hossain MS, Rahman GT, Zakaria CM, Zahan, MK (2017) Physiochemical and Antibacterial Activity Investigation on Noble Schiff Base Cu(II) Complex. American Journal of Heterocyclic Chemistry 3(4): 37-41.

[24] Patel, KM, Patel KN, Patel NH, Patel MN (2001) Synthesis, characterization, and antimicrobial activities of some transition metal complexes with a tridentate dibasic Schiff base and bidentate 2, 2'-bipyridylamine. Synth. React. Inorg. Met-Org. Chem. 31: 239-246.

[25] Temel H, Cakir Ü, Ugras HI, Sekerci M (2003) The Synthesis, Characterization and Conductance Studies of New Co(III), $\mathrm{Cu}(\mathrm{II}), \mathrm{Ni}(\mathrm{II})$ and $\mathrm{Zn}(\mathrm{II})$ Complexes with Schiff Base Derived from 1,2-bis-(o-aminophenoxy) Ethane and Salicylaldehyde. J. Coord. Chem. 56: 943-951.

[26] Liang Y, SU B, Zhao I, Sun W (2004) The Synthesis of New Asymmetric Double Schiff Bases Containing a New oAmino Benzoic Acid Derivative. Synthesis Communications 34: $3235-3242$.

[27] Venkataraman NS, Kuppuraj G, Rajajopal S (2005) Metalsalen complexes as efficient catalysts for the oxygenation of heteroatom containing organic compounds-synthetic and mechanistic aspects. Coord. Chem. Rev. 249: 1249-1268.

[28] Mohamed GG, Omar MM, Hindy AM (2006) Metal complexes of Schiff bases: preparation, characterization and biological activity. J. Turk. Chem. 30: 361-382.

[29] Diego M, Veronica D, Claudia P, Jean PT, Sandra S (2010) Synthesis, characterization and antioxidant activity of water soluble Mn (III) complexes of sulphonato-substituted Schiff base ligands. J. Inorg. Biochem. 104: 496-502.

[30] Khalil M, Ismail E, Mohamed G, Zayed E, Badr A. (2012) Synthesis and characterization of a novel schiff base metal complexes and their application in determination of iron in different types of natural water. Open J. Inorg. Chem. 2: 1321.

[31] Abu-El-Wafa, SM, El-Wakiel NA, Issa RM, Mansour RA (2005) Formation of novel mono-and multi-nuclear complexes of $\mathrm{Mn}(\mathrm{II}), \mathrm{Co}(\mathrm{II})$ and $\mathrm{Cu}(\mathrm{II})$ with bisazo-dianils containing the pyrimidine moiety: Thermal, magnetic and spectral studies. J. Coord. Chem. 58: 683-694.

[32] Etaiw SH, Abd El-Aziz DM, Abd El-Zaher EH, Ali EA (2011) Synthesis, spectral, antimicrobial and antitumor assessment of Schiff base derived from 2-aminobenzothiazole and its transition metal complexes. Spectrochim. Acta A 79: 13311337.

[33] Ueda JI, Takai N, Shiazue Y (1998) Reactive Oxygen Species Generated from the Reaction of Copper (II) Complexes with Biological Reductants Cause DNA Strand Scission. Arch. Biochem. Biophys 357: 231-239.
[34] Radhakrishnan PK (1986) Complexes of lanthanide perchlorates with 4-N-(2'-hydroxy-1'-naphthylidene) aminoantipyrine. Polyhedron 5: 995-998.

[35] Maurya RC, Mishra DD, Pandey M, Shukla P, Rathour R (1993) Synthesis and spectral studies of octacoordinated dioxouranium (VI) complexes with some Schiff bases derived from 4-Acetyl-2,3-Dimethyl-1-(4-Methylphenyl)-3Pyrazoline-5-One and aromatic amines. Synth. React. Inorg. Met. Org. Chem. 23: 161-174.

[36] El-ajaily MM, Maihub AA, Hudere SS, Ben Saber SM (2006) Nickel II Chelate of Schiff base derived from 4-dimethylamino-benzaaldehyde with Systeine. Asian Journal of Chemistry Society 18: 2427- 2430.

[37] Morad, FM, EL. ajaily MM, Gweirif SB (2007) Preparation, Physical Characterization and Antibacterial Activity of Ni (II) Schiff Base Complex. J. Sci. and Its Appl.1: 72-78.

[38] Hossain MM, Bashar MA, Khan MN, Roy PK, Ali MS, Farooque MA (2018) Preparation, Physical Characterization and Antibacterial Activity of Ni (II), Cu (II), Co (II), Cd (II), Zn (II) and Cr (III) Schiff Base Complex Compounds. Sci. J. Chem. 6: 17-23.

[39] Agwara MO, Ndifon PT, Ndosiri NB, Paboudam AG, Yufanyi DM, Mohamadou A (2010) Synthesis, Characterization and Anitimicrobial activities of Cobalt (II), Copper (II) AND Zinc (II) Mixed-ligand Complexes contacting 1,10-Phenanthroline and 2,2-Bipyridine. Bull. Chem. Soc. Ethiop. 24(3):383-389.

[40] Tumer M, Celik C, Koksal H, Serin S (1999) Transition metal complexes of bidentate Schiff base ligands. Transition Metal Chemistry 24: 525-532.

[41] Singh D, Singh VS (2016) Phytochemical Analysis and Antimicrobial Activity of Chloroform Extract of Abutilon indicum. American Journal of Applied Chemistry 4(6): 242246.

[42] Fatondji HR, Kpoviessi S, Gbaguidi F, Sika KC, Gbenou J, Accrombessi GC, Moudachirou M, Poupaert J (2018) Synthesis, Characterization and Antimicrobial Properties of Some 1,3,4-Thiadiazolines. American Journal of Applied Chemistry 6(2): 64-70.

[43] Patel RN, Singh N, Shukla KK, Chauhan UK, Gutierrez JN, Castineiras A (2004) Magnetic, Spectroscopic, Structural and Biological Properties of Mixed-ligand Complexes of Copper(II) with $\mathrm{N}, \mathrm{N}, \mathrm{N}^{\prime}, \mathrm{N}^{\prime \prime}, \mathrm{N}^{\prime \prime}$-Pentamethyldiethylenetriamine and Polypyridine ligands Inorganica Chimica Acta 357: 24692476.

[44] Mohamed GG*, Omar MM, Ibrahim AA (2009) Biological activity studies on metal complexes of novel tridentate Schiff base ligand. Spectroscopic and thermal characterization. European Journal of Medicinal Chemistry 44: 4801-4812. 